\title{
Leadership of School's Headmaster in Taking Decision of Curriculum Development in The State Elementary School (SDN) 101786 Helvetia, Deli Serdang District
}

\author{
Nurtuah Tanjung, Nurika Khalila Daulay $^{2}$ \\ ${ }^{1}$ Master Student of Islamic Education Management in FITK, UIN-SU, Indonesia \\ ${ }^{2}$ Lecturer in of Islamic Education Management in FITK, UIN-SU, Indonesia
}

\begin{abstract}
:
This study aims to describe the principal's leadership in decision-making curriculum development at Elementary School 101786 Helvetia Research includes principal leadership, decision-making, and curriculum development. This research uses qualitative research type with case study approach. The location of the research is Elementary School 101786 Helvetia District Labuhan Deli Deli Serdang Regency North Sumatra Province Source. The method according to the title of this study researchers using qualitative approach, the data in this study is, principals, teachers, school committee. The conclusions of this research are: 1. Leadership of principal in decision making of curriculum development at elementary school 101786 Helvetia "to make decision of curriculum development by making decision involving party, such as teacher, school committee, school supervisor, and decision making staff coordination meetings, in a participatory manner ".2. Leadership behavior, principals point to the style and strategy of a principal performing the principal's leadership task. Among the principal's effective leadership behaviors, although they still need to be improved for better, can be seen in the leadership style that always brings in coordination meetings with school committees, school supervisors, teachers and staff. 3 . The principal's strategy in informing the decision-making result of curriculum development between headmaster and teacher is done directly in the form of face to face and indirectly in the form of telephone, sms, or letter.
\end{abstract}

Keywords :

leadership of the principal; decision-making; curriculum development.

\section{Introduction}

Relating to decision making Decision making is an alternative choice of action. This is related to the management function. For example, when managers plan, manage, control, they make similar decisions with Hasbi Abduh (2015: 26). An organization is a place for the operation of management because that is where management activities become one of the sub-systems of the organizational system. Management becomes a technique or tool that moves the organization towards achieving desired goals. In the context of the manager's task, decision making is one of the manager's roles called the decisional role. In determining managerial actions a manager is required to dare to make decisions both on the consideration of individuals with his authority as a leader, as well as decisions from the results of deliberation by paying attention to the thoughts, feelings or input from members of the organization. Likewise, it can be seen in the decision making at state elementary school 101786 Helvetia that the decision making process and the results have not been fully implemented by all stakeholders, including school committees, teachers and staff.

Related to curriculum development, the new policy on the revision of the 2013 curriculum in 2016 and its implementation and application at the elementary school level has not been evenly distributed throughout the classrooms such as those implemented at state elementary school 101786 Helvetia where the new implementation is implemented at grade 1 (one) and grade 4 (four ), as well as the Education Unit Level Curriculum (KTSP) still going on in class 2 (two), 3 (three), 5 (five), and 6 (six) certainly requires good implementation as well, therefore handling of the two 
curriculum is needed in one school or institution. Decisions to be carried out by all components in State Elementary School 101786 Helvetia should be done in a deliberative decision making involving all parties including headmasters, teachers, school committees, school supervisors as well as stap and administration, not taken by the principal themselves which later decisions may not be supported by existing components at the school, in line with A. Sulaeman (2015: 72). The discourse on Islamic education, especially those with a platformalistic variant with the main variants of teaching and learning activities, cannot be separated from curriculum problems as innovative entities that are constantly changing. Where this is something common in the scope of social reality as a natural law that needs to be addressed flexibly. This paradigm "seems" to form a prevalence on the limits of change in Islamic education, because it cannot be separated from natural law that will undermine Islamic education. to carry out reconstruction and place its existence in accordance with the demands of reality or the needs of stakeholders who continue to experience changes. Although the flow of reality continues to flow changes that demand other things in the world of Islamic education, but the capacity of curiosity needs to be determined as spiritual in the life of Islamic educational institutions and the construction of Islamic education material. That is, the dynamics of reality need to be balanced with constructive-solutive movements of Islamic education to remain on the principle of conformity. Thus, the curriculum in education (Islam) becomes a kind of barometer of success or at least teaching and learning activities, where the curriculum in this context is the core of education and it has an influence on all educational activities.

\section{Theoretical Review}

The Trait Theory Approach, according to trait theory, only individuals who have certain qualities can be a leader. The individual is better known as a super person (great men). This theory confirms the idea that some individuals are born to have traits that naturally make them individuals. 2). Leadership theory $X$ and $Y$, The effect of theory $X$ and $Y$ is the emergence of what is called a self-fulfilling prophecy phenomenon, where leaders make estimates, assume beforehand, prejudge or formulate beliefs that make reality because leaders predict them and acting as if it were true (Safaria 2004: 39-40).

Miftah Thoha, (2016: 34-36) added that there is a group theory which in this leadership has a basic development which is rooted in social psychology. Classical exchange theory helped him as an important basis for the group theory approach. This group theory assumes that, for the group to achieve its goals, there must be a positive exchange between the leader and his followers.

The writer concludes that leadership is the ability of a dream to influence and move others to work together to achieve a group goal both formally and informally. In order to evaluate or to assess the ability of a leader it is done by observing and recording the characteristics and qualities or the quality of his behavior, which is used as a criterion for assessing his leadership.

\section{Research Methodology}

The location of this research is Jalan Bambu Pasar IV, Helvetia Village. The full name of the school where this research is; State Elementary School 101786 Helvetia Labuhan Deli District Deli Serdang Regency with an area of $2030 \mathrm{~m} 2$ and a building of $900 \mathrm{~m} 2$. This thesis starts in October 2017 until December 2017 where this thesis has been studied. And continued with March 2018.

In accordance with the title of the study, researchers used a qualitative approach. The notion of qualitative research is as follows: 
That qualitative research is one of the research procedures that produces descriptive data in the form of speech or writing and the behavior of the people observed. A qualitative approach is expected to be able to produce in-depth descriptions of speech, writing, and / or behavior that can be observed from an individual, group, community, and / or particular organization in a particular context setting which is reviewed from a wholly, comprehensive and holistic perspective. (Bogdan, Robert and Svenven Taylor 972: 21-22).

\section{Discussion}

The leadership carried out by the school principal at state elementary school 101786 Helvetia, although the headmaster's authority was very large, in his leadership he continued to coordinate with various government leaders, in this case the Office of Education, School Committees, school supervisors, school supervisors and teachers and staff. Although Walaupum still looks stiff in his leadership because he is still newly appointed as a headmaster, everything is still centered on government policy, in this case the Education Office.

Principals in making curriculum development decisions by involving other than school principals, school committees, school supervisors and all teachers and participants so that all decisions can later be accepted and implemented by all school components, so the results of curriculum development decisions in the school do not seem to be done alone by the principal.

The principal's behavior in the decision-making process of curriculum development in state elementary school 101786 Helvetia. The success of the headmaster of course can also be seen from how the principal's behavior in leading, then the figure of the school principal who behaves and takes care of all components of the school in order to realize good decisions in democratic ways that do not take policies or unilateral decisions that will lack support and participation from teachers, staff and school committees.

Behavior or traits of a leader in this case the principal has not been fully mastered by the principal depicted in every meeting the traits or behaviors referred to are like bodily strength, roaniah, emotional, social, honesty as mentioned by George R. Terry quoted Omar Mohammad Al-Toumy A-Syaibany (1984: 478). Theory of Nature according to George R. Terry is as follows: 1) Strength. Physical strength and rokhaniah are basic conditions for leaders so they have the endurance to face various obstacles. 2) emotional stability. Leaders with stable emotions will support the achievement of a harmonious, peaceful and harmonious social environment. 3) Knowledge of human relations. Leaders have knowledge about the nature, character, and behavior of subordinates in order to assess the strengths / weaknesses of subordinates in accordance with the tasks given. 4) Honesty. A good leader must have high honesty both to himself and to subordinates. 5) Objective. The leader must be objective, look for tangible evidence and causes of an event and provide rational reasons for his rejection. 6) Personal impulse of desire and willingness to become a leader must emerge from the heart so that it is willing to provide service and dedication to the public interest. 7) Communication skills. Leaders are expected to be good at writing and speaking, easy to grasp the intentions of others, adept at integrating different opinions and streams to achieve harmony and balance. 8) Teaching ability. Leaders are also expected to be good teachers, who bring people to learn on certain targets to increase knowledge, skills so that their subordinates can be independent, willing to provide loyalty and participation. 9) Social skills. He is friendly, open, willing to respect the opinions of others, so he can foster good cooperation. 10) Technical skills or managerial skills. In the view of Islam a good leader is: 1) Sidik, Sidik means true. True in words and deeds. able to make himself a good priest in carrying out the commands 
of Allah as Caliph on earth 2) Amanah, Amanah has a truly trustworthy meaning, still remember why the Prophet was dubbed the title 'Al-Amin'? The Prophet Muhammad was entitled to the noble title because he always did his best if there were matters for which he was responsible. Every word spoken by the Prophet Muhammad is honesty. Learning from the nature of the Prophet is not as easy as existing theories.

Before the decision is made, the principal as the school leader should be obliged to communicate matters relating to the object or material to be decided so that in decision-making meetings all the components present understand and know the issues and problems to be decided, as well as the results of the decision, the principal must communicate either through letters, short messages (sms) or through telephones. So that all components relating to educators and education do not confuse the results of the decisions taken.

Although in fact there is still a need for school principals to continue to learn how the concept of leadership actually is, both in terms of leadership itself, the behavior of principals in the decision making process of curriculum development and the strategies undertaken by principals in informing the results of curriculum development decisions that continue and continue.

The success of a school principal in making decisions is also influenced by the success in delivering strategic information to all components of the school both directly and indirectly that the principal is good at delivering information such as through direct and indirect coordination meetings such as cellphone short messages ( sms, WA), announcement board. However, it should be remembered that the use of telephone to convey information and messages must be clearly concise and can be understood and understood by the recipient, because a misunderstanding of the contents for the purpose of the information can be cancelled.

\section{Conclusion}

Principals' leadership in making curriculum development decisions at State Elementary School 101786 Helvetia "makes decisions on curriculum development by making decisions involving many parties, such as teachers, school committees, school supervisors, and decisionmaking staff through coordination meetings, in a participatory manner" . Personality behavior of leadership, although the influence of the principal's authority in decision making curriculum development, but every decision is still held a coordination meeting of the principal with the school committee, teachers and staff. although it still needs to be improved to be better, so that it can protect all stakeholders of state elementary school 101786 Helvetia. The strategy undertaken by the school principal in informing the results of decision making curriculum development between the principal and the teacher is done directly in the form of face to face and indirectly in the form of telephone, sms, announcement or letter.The strategy undertaken by the principal in informing the results of decision making curriculum development in state elementary school 101786 Helvetia. the implementation of the strategy undertaken by the principal in informing the results of decision making curriculum development at State Elementary School 101786 Helvetia include: a good communication climate between the principal and the teacher, the available communication media as well as the loyalty and dedication of each teacher. 


\section{References}

Bafadal, Ibrahim. (2012) Seri Manajemen Peningkatan Mutu Pendidikan Berbasis Sekolab: dari Sentralisasi Menuju Disentralisasi. Jakarta: Bumi Aksara.

Duryat, Masduki. (2016) Kepemimpinan Pendidikan: Menegubkan Legitimasi dalam berkonsentrasi di Bidang Pendidikan. Bandung: Alfabeta, 2016

Engkoswara \& Komariah, Aan. (2016) Administrasi Pendidikan. Bandung: Alfabeta.

Fahmi, Irham. (2014) Manajemen Kepemimpinan: Teori dan Aplikasi. Bandung: Alfabeta.

Hadijaya. Menyusun Strategi Berbuah Kinerja Pendidik. Efektif. Medan: Perdana Publishing, 2013.

Hadi, M. Strategi Kepala Madrasah Dalam Meningkatkan Mutu Pendidikan Pada Min Buengcala Kecamatan Kuta Baro Kab Aceb Besar, Volume IV Nomor 02, 2014.

Hafied Cangara. Perencanaan dan Strategi Komunikasi. Jakarta: Raja Grafindo Persada, 2013.

Safari, Triantoro, (2004) Kepemimpinan.Graha Ilmu. Yogyakarta.

Thoha, Miftah. (2012) Kepemimpina Dalam Manajemen.

Hanun, Farida. Akreditasi Madrasah Sebagai Kunci Keberbasilan dalam Pemenuban Standar Nasional Pendidikan (SNP). Jurnal EDUKASI Volume 13 Nomor 1,2015 